\title{
Electronic Government, Digital Invisibility and Fundamental Social Rights ${ }^{1}$
}

\section{Governo Eletrônico, Invisibilidade Digital e Direitos Fundamentais Sociais}

\author{
Justo Reyna ${ }^{1}$ \\ Emerson Gabardo ${ }^{2,3}$ \\ Fábio de Sousa Santos ${ }^{2}$ \\ ${ }^{1}$ Universidad Nacional del Litoral, Santa-Fé, Santa-Fé, Argentina \\ ${ }^{2}$ Pontifícia Universidade Católica do Paraná, Curitiba, PR, Brasil \\ ${ }^{3}$ Universidade Federal do Paraná, Prado Velho, PR, Brasil
}

\begin{abstract}
The article aims to analyze the impact of the digitalization of Public Administration activities, labeled Electronic Government, on the ability to fulfill fundamental social rights. It adopts as a base the concept of digital invisibility, defined as the inability to have access to the digital government, mainly based on empirical data to access the world wide web. It uses the deductive methodology from the bibliographic analysis about the matter. It verifies the hypothesis that the use of technological tools as unique mediators poses a particular risk to social rights due to digital invisibility. Taking into account the objective dimension of fundamental rights, it concludes that the State must guarantee digital access broadly, especially to vulnerable groups. State recipients should not be imposed insurmountable obstacles in the search for the fulfillment of constitutional promises.
\end{abstract}

Keywords: E-Government. Development. Fundamental Social Rights. Digital Invisibility. New Technologies.
Resumo: $\mathrm{O}$ artigo tem como objetivo analisar o impacto da digitalização das atividades da Administração Pública, rotulada de Governo Eletrônico, na aptidão para adimplemento dos direitos fundamentais sociais. Adota-se como base o conceito de invisibilidade digital, definida como a incapacidade de ter acesso ao governo digital, especialmente a partir de dados empíricos de acesso à rede mundial de computadores. Utiliza-se a metodologia dedutiva a partir da análise bibliográfica a respeito da matéria. Verifica-se a hipótese de que a invisibilidade digital oferece especial risco aos direitos sociais quando as ferramentas tecnológicas são utilizadas como mediadoras únicas. Tendo em conta a dimensão objetiva dos direitos fundamentais, conclui-se que o Estado deve garantir o acesso digital de forma ampla, notadamente, aos grupos vulneráveis. Acredita-se que não devem ser impostos aos destinatários das ações estatais obstáculos intransponíveis na busca pela concretização das promessas constitucionais.

Palavras-chave: Governo Eletrônico. Desenvolvimento. Direitos Fundamentais Sociais. Invisibilidade Digital. Novas Tecnologias.

${ }^{1}$ This study was financed in part by the Coordenação de Aperfeiçoamento de Pessoal de Nível Superior - Brasil (CAPES) - Finance Code 001.

Recebido em: 30/06/2020

Revisado em: 31/07/2020

Aprovado em: 03/08/2020 


\section{Introduction}

Technological advancement has provided humankind with new ways of relating and performing tasks with less effort before being very difficult to perform. Contemporaneity and its complexity bring the emergence of increasingly powerful technological tools. In the brave new world, the internet has left personal computers and invaded everyday things. It is common now to see features that were almost exclusively linked to human nature to be mimicked in machines. The machine is also capable of learning, contracts have become intelligent, data is growing, and strategy is gaining importance. However, paradoxical situations start to emerge when the human being is seen as a central element of life in society because the evolution of digital technologies has a profound impact on several fields of human life.

The domain of fundamental rights, especially in realities of profound inequality, as a Brazilian, imposes on the legal scientist with techie features (HARTLEY, 2017), a new look at consolidated concepts in the field of constitutional and administrative Law. The changes that technology brings are not always about new rights or situations but are also about old questions, ins a new environment. One could argue that the real challenge is not in the new situations but the necessity of address old problems with new technological features or in the traps that lie behind the view of technology solutions as an all might problem solver. Every new solution can bring along a new problem.

As an element of society, the figures by which the State is manifested also suffer influence and must transform themselves, adapting to a reality that demands more and more digital action by the Public Administration. Therefore, it is necessary to take into account that the possibility of introducing technological tools in the Administration alters the equation referring to the model of State action in that field, possibly changing the results or assumptions of a given action. There is no doubt that the new rights require the resizing of administrative Law (FREITAS, 2019, p. 27). 
Fundamental rights then emerge as one of the most relevant themes in constitutional Law, insofar as they contain state commitments - updated by digital transformation - towards individuals. This category of rights must also be re-read under a new lens (such as freedom of expression in the digital context). However, fundamental social rights remain closely linked to the material conditions of a dignified human existence (HACHEM, 2013b, p. 620). Even though the mediation of the functioning of state figures comes to rely on technological tools, the reality of many individuals has a degree of socioeconomic asymmetry so marked that it prevents them from following the State of the art of $21 \mathrm{st}-$ century technologies. Internet and smartphone are entirely unaware of the reality of a considerable portion of the population.

Should these people be required to prioritize spending on technological tools that allow access to fundamental social rights? Society denies access to essential elements of the human condition, such as housing, education, or food security for vulnerable groups. So, how should the state response to this problem be? That is the fundamental question that the text intends to answer. The proposed hypothesis is that it is impossible to impose the burden of vulnerable groups on providing for themselves the digital tools to guarantee their dignity and citizenship. Digital invisibility poses a particular risk to social rights when technological tools are used as unique mediators.

\section{Public Administration Electronic Government and the fulfillment of State functions}

The term Public Administration is a typical label and can be roughly defined as a set of entities and organizations holding administrative functions. In Brazil, based on the constitutional text, it is possible to fit all legal entities created by the State into three types: autarchies, foundations, and state-owned companies. The other form of administrative bodies (though not qualified as persons) are agencies. In contrast to the liberal conception, the State's functions, in the context of the Social State, also depend on a new conception of Public Administration, directly responsible 
for the supply of goods and the provision of services (BITENCOURT NETO, 2017, p. 291). Therefore, the term Public Administration represents the subjective institutions by which the State materializes the exercise of the functions of police power, fostering, public services, or economic activity in the strict sense.

Inserted in the reality in which technological innovation occurs in an unprecedented step (KANE et al., 2019, p. 30), Public Administration is not unaware of the changes in the world in which it operates. It is not possible to point out the use of information technology in state agencies as a novelty. The creation of the Federal Data Processing Service - SERPRO dates back to the 1960s. However, more incisive measures towards Electronic Government were adopted in 2000 (NOHARA; COLOMBO, 2019 , p. 88), not by conscious choice of need for modernization, but due to the imminent occurrence of the "millennium bug" (BARBOSA, 2009, p. 49). The Federal Office of Audits already recognizes that it is difficult to envision any action developed by the bodies and entities of the Federal Public Administration that does not depend directly or indirectly on Information Technology (IT) (BRASIL, 2012b).

It is possible to define Electronic Government as a form of knowledge organization that will allow many acts and merely bureaucratic structures to disappear and the execution of tasks that require a more complex human activity to be facilitated (ROVER, 2005). The United Nations also refers to how, when making use of digital technologies, governments can answer for the adversities arising from natural or human-made disasters, as well as several other types of crises (UNITED NATIONS, 2018, p. XXIII). However, a complete concept addresses three different dimensions: Electronic government, Electronic Administration, and Electronic governance (BRAGA; GOMES, 2015, p. 527). Electronic government is nothing more than an expression that designates the adoption, by the entities of the Public Administration, of the tools of Information Technology for the execution of their functions and activities: the Public Administration through the lens of digital technology. 
The United Nations attributes Brazil to 44th position in the Global Electronic Government Ranking (2018), with a high score in the online service component $(0.926$, where the maximum is 1$)$, well above the world average for this item $(0,4343)$ and the average of developed countries (0.6503). Such classification is compatible with the high number of websites of public agencies on the world wide web. Moreover, it is also compatible with traditional administrative and legal structures (such as those above SERPRO) or figures from analogical reality, but fully fluent in the "digital language" (such as the procurement procedure of electronic auction provided for in Federal Law 10.520/2002; or the Transparency website provided for in article 48, sole paragraph, II, of Complementary Law 101/2000). In fact, technology has allowed the expansion and opening of new channels for citizen's political participation in public affairs management and in the control of the Administration (MACHADO; RESENDE, 2019, p. 769). It is interesting insofar as the primary function of the entire state apparatus is, after translating the stimuli of society's demands into the language of the Rule of Law, offering responses capable of satisfying the needs that present themselves in the social scenario (OLIVEIRA, 2010, p. 160).

In a state that adopts the federative model, such as Brazil and Argentina, it is possible to affirm that the use of information technology tools also has the potential to increase the interaction between the various federative entities (CRISTÓVAM; SAIKALI; SOUSA, 2020, p. 218) either for the construction of networked policies or for the use of more robustly compared experiences. Here, a multidimensional view of administrative Law is favored (REYNA, 2011), before the action of the digital environment as a catalyst for interactions between the orders of the various entities involved to the extent that it enables deterritorialization. In this perspective, federalism gains a digital dimension, allowing the Federation's institutional mosaic to have an adequate dimension of its pieces and its ensemble, with the possibility of observing respect for domestic and regional particularities.

The moment is favorable for the adoption of new methods of operation of the State bureaucracy since it is recognized to wear and tear in the Brazilian public administration model. The typical Administration 
of the 20th century has created difficulties in achieving agility and quality in meeting social demands (MODESTO, 2010, p. 397). Furthermore, there is much room for improvement when focusing on new technologies such as data science, artificial intelligence, deep learning, blockchain, government as a platform, smart cities, and many other innovations. Sooner or later, although due to the obsolescence of the analog world, Public Administration will have to become digital (FREITAS; TEIXEIRA, 2019). In addition to the tools used, the Administration's modernization cannot do without the holistic analysis of the State's role and its channels of action, requiring a consequentialist analysis of the Public Administration. However, the technical aspects, however relevant, should be treated only as tools (REYNA, 2014a, p. 37).

The challenges to public officials who need to deal with this new reality are clear. It will be necessary to transform actions, structures, institutes, and procedures, as well as the relationship with the citizen, which is a fundamental reason for Public Administration. New technological tools must promote rights, recognizing the existing inequalities in society and their peculiar interactions with technology (CORVALAN, 2017, p. 29-30).

\section{Fundamental Social Rights, Objective Dimension and Provision Function}

The 1988 Constitution, resistant to more than 100 Constitutional amendments, preserves to date the clauses designed to transform society, consecrating the State's duties to implement public policies that guarantee the satisfaction of the individual's basic needs, a duty corresponding to social benefits (BRANDÃO, 2008, p. 477). The fundamental rights label is one of the most relevant signs of the Brazilian constitutional text. The positivization of fundamental rights promotes the limitation of political power in favor of the protection of the individual (BRANDÃO, 2008, p. 452). The constitutional text establishes the content of such rights, regardless of normative legislative regulations (HACHEM, 2013a, p. 368). The new constitutional text was generous in dealing with 
fundamental rights, giving Brazilian citizens the title to a series of legal positions hitherto not guaranteed by the national legal system (HACHEM, 2013a, p. 345).

The legal positions of fundamental rights have their content defined by the constitutional norms, establishing a special legal relationship between State and individual (BERNAL, 2007, p. 83/85). Fundamental Law is, in a broad sense, a bundle of legal positions in which the legal system invests the holder of a fundamental right. However, this view unfolds in two dimensions: subjective and objective.

In its subjective dimension, the citizen becomes a creditor of the State, even if any violation of rights occurs in the private sphere (DUQUE, 2014, p. 299). Commonly associated with this dimension - but which does not end there - is the defense function, which constitutes the subtraction of the State from the possibility of action in a specific sphere of determination (NOVAIS, 2003, p. 72). There is, for example, a close relationship between freedom of expression, a fundamental right, and the domain of Information and Communication Technologies (CORVALÁN, 2017, p. 38).

The objective dimension of fundamental rights is reflected in the State's obligation to create real and adequate conditions for the enjoyment of that legal asset by citizens, instituting on the factual and legal levels organizational structures and procedural mechanisms suitable for their protection. In this dimension, fundamental rights gain a higher degree of abstraction, ceasing to be exclusively the mandatory vector of a given State-citizen legal relationship and becoming objective values, that is, admitted assets that, due to their constitutional recognition, impose themselves on all (NOVAIS, 2003, p. 64). One of the practical consequences of the objective dimension of fundamental rights is the prohibition of retrogression in matters of social rights, as legal certainty is not only an individual subjective right opposed to the State but is a core element of the objective order of values of the Rule of Law (SARLET, 2015, p. 476).

Social rights have two distinctive characteristics that allow their identification: first, the object intended to protect concerns access to 
social, cultural, and economic assets, that is, to a dignified individual existence; second, scarcity is a mark of such goods. Therefore, it is possible to obtain them through the market if individuals have resources (NOVAIS, 2010, p. 41). At this point, it is necessary to make a significant reservation: all fundamental rights, whether they are marked as fundamental social rights or not, are indistinguishable in the following characteristics: I - Transindividual ownership simultaneously with individual ownership; II - They stipulate to the State obligations of factual nature and normative nature; and III - Impose a duty of abstention on the State. The statement intends to comb the idea that the rights of freedom do not correspond to actual payments or that social rights necessarily lack regulation, requiring public expenditure for their implementation (HACHEM, 2013b, p. 621).

Individual freedoms are examples of rights that are typically identified by their defense function. The digital environment, a fertile ground for the exercise of freedom of expression, is useful in examples that highlight the collective marks among fundamental rights. The expression of an opinion in a given social network is protected by the right to free expression. If the social network resolves, without just cause, to restrict the right of a given user, the individual right to move the state machine appears in order to see the abstention of the individual materialized by his sphere of freedom materialized. Such movement has costs. Otherwise, if the same demonstration is not part of the sphere of freedom that belongs to it, it is up to the State to safeguard the attacked rights (honor, image, or eventually the fairness of an electoral election, when it takes place in an environment of political electoral dispute). It should be noted that such offending rights can also be justified. The State movement aimed at balancing the irregular exercise of freedom of expression in a digital environment is also an activity that demands the use of the expensive justice and police apparatus.

The provision of fundamental rights is defined by the demand for positive actions by the State entity. It extends from the protection of the citizen through rules of criminal Law to the establishment of organizational and procedural rules (ALEXY, 2008, p. 442). The definition encompasses, in addition to direct benefits to beneficiaries, the 
awareness that the exercise of democratic freedoms, such as the right to vote, depends on normative activities (normative definitions of electoral capacity, dates) and organizational activities (an institution that will be responsible for organizing the election). However, in the consciousness of the welfare state, as an activity that is its own, to take responsibility for the civilizing growth of society, it is necessary to recognize that social rights' function, as a rule, allows respect for human dignity. It guarantees the exercise of freedom with attention to human development (BITTENCOURT, 2010, p. 100).

For the materialization of such fundamental rights, Public Administration makes use of all its action tools: police power, fostering, public service (public utilities), and the exercise of economic activity in the strict sense. Policies appear here as a construction complicated and broad. In other words, public policy must be understood as the coordination of means available to the State, harmonizing state and private activities to achieve socially relevant and politically established objectives (BITTENCOURT, 2013, p 43-44). Given the objective dimension of fundamental rights, the policy also constitutes a form of self-linking by the Administration with a specific course of action, representing a commitment to a specific allocation of public resources (VALLE, 2016, p. 148).

\section{Fundamental Social Rights and Digital Invisibility}

There is a fundamental mismatch between the adoption of new technologies by people, organizations, and institutions, forming what Gerald Kane et al calls asymmetries (2019, p. 30). It is possible to recognize three different species: the first asymmetry is that of adoption: technology evolves at a faster rate than people's ability to adopt them; the second is the adaptation, which lies between the ability of people to adapt to new technologies and the capacity of organizations (public Administration and companies) to incorporate them; and the third is assimilation asymmetry, which refers to the mismatch between adaptation and the existence of formal institutions (e.g., legislation) about a given 
technology. The technology of autonomous cars is a sufficient example to exemplify the mismatch, as the technology exists, it is already commercially available, but it is challenging to implement (FREY, 2019, p. 309).

Electronic government is the result of the assimilation and adaptation of the State to various technologies offered by contemporary times, among which, of course, the internet stands out. Galindo Ayuda (2012, p. 40-41) defends the presence of the internet as a mediation mechanism for the exercise of concrete rights within the scope of Public Administration, without the need for physical presence at the entity's headquarters. At first sight, the idealization seems to materialize the guideline for the optimization of public resources, establishing even greater proximity between Administration and the citizen. They will now be able to accompany their formal demands from the comfort of their home. The real world is mostly analog, and digital information must be converted to the real world (ROVER, 2019, p. 209). Conversion and conversion would, in this case, be delegated to the interested citizen.

The fact is that the use of computers, cell phones, and, above all, the internet has introduced profound changes in the ways of organizing work in companies and also in the daily lives of individuals. However, technological wonders overshadow the reality of a multitude of excluded from the digital world, and fiction presents an instructive example. The film I, Daniel Blake (2016), portrays the journey in which the protagonist is prevented from working due to heart disease and suffers from the bureaucratic and technological obstacles necessary to obtain a benefit that would enable him to support his livelihood. Access to the computer and the internet is one of the challenges faced to obtain the right sought. The character enlists the help of neighbors or strangers to fill in various documents addressed to the Public Administration and dies without seeing his right met.

According to Brazilian Institute of Geography and Statistics (IBGE, 2020), in 2018, 74.7\% (seventy-four points seven percent) of people over ten years of age used the internet. If the fact that a third of the Brazilian population does not have access to the tool was not enough, 
the sociological profiles of the research mentioned above further widened the social gap. For those over 60 (sixty) years old, only $25 \%$ (twenty-five percent) used the internet. Of the people who did not use the network, $41,6 \%$ (forty-one point six percent) stated that the reason would be for not knowing how to use the internet while for $17,5 \%$ (seventeen points five percent) the reason for not using is the cost of access. In 2017 the same Institute (BRASIL, 2018) had shown that of those who have no education, only $11.4 \%$ (eleven points four percent) had access to the internet; of those with incomplete primary education, $50.5 \%$ (fifty point five percent). In the non-employed population, exclusion borders on half of Brazilians, only $56.8 \%$ (fifty-six point eight percent) had internet access. The internet and the digital world are not, therefore, inclusive.

Fiction seems to materialize in the Brazilian reality. When the emergency benefit of Law 13,982 of April 2, 2020, is observed, instituted as one of the measures to face the public health emergency of international importance resulting from the COVID-19 Coronavirus (BRAZIL, $2020 \mathrm{~b}$ ). It is possible to state that because of art. 2 of the referred rule, the target public of the public policy transmitted is composed of the vulnerable portion of the population. Article 5, II of Decree n. 10,316 of April 7, 2020, however, stipulates that access to the benefit depends on filling out the form provided on the "digital platform." It is observed that the more technological advances accumulate, how a specific fundamental right can be realized are expanded. That does not mean, however, an equal expansion of access.

Technology can serve as a bridge to reach individuals more efficiently. This quality, however, does not always turn into a beneficial situation when vulnerable groups are focused. Therefore, it is necessary to carry out an evaluative analysis of technological devices (MAGRANI, 2019 , p. 214). The use of technological mediation to register beneficiaries in the case promotes the exclusion of a considerable portion of the population that does not have access to the world wide web; it is exclusionary, unreasonable and affronts the objective dimension of fundamental social rights, in particular, that of the dignity of the human person. This action demonstrates the need for a political approach to the legal and technological problems of social rights (NOVAIS, 2010, p. 25). 
When it comes to the interaction between fundamental rights in an unequal society and with a high digital exclusion rate, such as the Brazilian one, there is an inversion of the logic of technological asymmetries. Organizations adopt or assimilate technology at a faster rate than people can access.

However, according to the Brazilian constitutional system, the wonders provided by technology cannot lead to a situation in which citizenship is only granted to those initiated in digital tools. In contrast, the others are exiled (BREPOHL; GONÇALVES; GABARDO, 2018), becoming real digital invisible. That is a problem because, in addition to a conflict between public interest and fundamental rights, there will also be conflicts between opposite fundamental rights in the concrete situation especially in emergencies. The response to be dated by the Administration is not easy and tends to generate negative externalities, whatever the decision was taken. An example of this situation has been the adoption of distance learning as a temporary substitute for face-to-face education due to social isolation needs during the COVID-19 pandemic. That is an evident hard case, which will inevitably generate some kind of disregard for fundamental rights, whether from the group that has visibility or those that do not.

It should also be noted that the migration of the administrative procedure to digital environments directly impacts what Correia (2016, p. 55) considers the central axis of administrative Law. Such migration should not have as much impact on procedures involving economic activities or higher educated professional categories, as is the case with the recent and still ongoing implementation of electronic systems for the management of documents in judicial proceedings. For these cases, the administrative procedure in digital media can even represent an efficiency gain. The same cannot be said for state actions directed at people in economic and social vulnerability situations. Two exits are visible at this point: the first is that it is necessary to coexist with digital and analog solutions. At the same time, society cannot undress direct or mediated non-digital access. Another possible way out is to start to see the right of access to digital tools for interaction with Public Administration as part 
of the organizational function (HACHEM, 2013b, p. 628) of fundamental rights mediated by technological access.

Even the participation of individuals in the construction of the guiding concepts of state actions is impaired since the common good itself is a concept built from the synthesis of interests of groups coexisting in the democratic space - by the recognition of consensus in a plural environment (CRISTÓVAM, 2019, p. 129). As the digital "arena" is the unique space for the exercise of several individual freedoms (such as freedom of expression), the lack of guarantee of access to technological tools for participation prevents the necessary interaction of the process of forming a public consensus.

Technology challenges Law, in particular administrative Law, adhering to pressures that already exist in the political and economic spheres. Furthermore, technological changes are daily and spread with unprecedented speed (VIANA; KREUZ, 2018, p. 57). The institutional complexities inherent to a federative system have special features since the distribution of constitutional powers of the different entities can be opposed to the realization of certain rights or provision of access routes to their realization.

There is a contrast here with the recognizable permeability of the borders of Law itself and Public Administrations vis-à-vis citizens, especially in a democratic environment (REYNA, 2014b, p. 47). The dilution of dichotomies and the reduction of institutional friction aimed restricting access to fundamental rights can gain strength in the digital environment. For example, a place of access to the worldwide web maintained by a municipality can be used to guarantee access to services federated states or federal digital services. However, the digital environment can also cause conflicts of competence, with overlapping public functions.

In this context, the State finds a plateau for the migration of its functions to a digital environment, insofar as the efficiency of Public Administration cannot be obtained at the cost of excluding from state protection people who do not fit in updated technological standards. On the other hand, in dichotomous situations, the State cannot fail to provide 
services that come to exist (temporarily or permanently) only in a digital environment. Therefore, there is an increasing need for creative solutions that take all the variables involved in the case.

In summary, the need is reinforced for the State to take real and apt measures to ensure the ideal realization of these rights (GOMES; FLORES, 2019), since the inability of the tool to materialize the fundamental right represents a restriction contrary to the constitutional model, which is that of a welfare state. Besides, any restriction on fundamental rights, even when constitutionally admitted, ends up representing a violation of subjective public Law (DUQUE, 2014, p. 299).

\section{Conclusion}

The challenges that new technologies impose must bring some adjustment to the contemporary jurist's pace. The development environment of Law is constantly changing (CORRALES; FENWICK; FORGÓ, 2017, p. 3); thus it is needed some course correction not only in the tools available for the jurists, legislators, and public administrators but mainly in the mindset of these actors in order to avoid inadequacies in their actions, products, and thoughts. The digital government must be seen as a reinterpretation of public Administration adapted to contemporary times' technological demands, with a view to the efficient performance of the State (GABARDO; HACHEM, 2018). A mindset attached to 19's century reality has a high risk of condemning their products to be unable to answer to problems of contemporary society.

Fundamental rights also need to be read, therefore, under the lens of technological developments, without, however, denaturing their substance or representing social retrogression. One must recognize that act as a censor of society's technological development is not to one of the goals of fundamental rights - though it may be one of its guidelines. However, one's must also not forget that this phenomenon has a sensible impact on individuals and their economic and social relations, relations with the government included. These impacts, unfortunately, are not always good ones, especially if taken int account the vulnerability of the individual as 
a factor. Any public policy or analysis of this subject must address this complexity in order to be taken seriously.

The contemporary State and his actors must pay special attention to fundamental social rights. They represent civilizing conquests that demarcate obligatory relations between the State and individuals (subjective dimension) and establish a valuation system that must coordinate public actions (objective dimension). Although it is also present in the so-called rights of defense, the service function is an element that is most noticeable in fundamental social rights.

Without showing an aversion to technological modernization, the realization of the provisional function of the subjective dimension of fundamental social rights cannot do without the fair offer of accessibility to the recipients of State actions, under the risk of constituting a real restriction on the fulfillment of the state obligation. As Freitas (2019, p. 24) points out, although analog administrative regulation does not make sense anymore, the digital model, in turn, is not enough. Difficult situations demand a sophisticated treatment of the subject, with caution and analysis not only of the consequences of the administrative decision but of the values involved.

The implementation of technological tools that do not take into account the social reality imposes an insurmountable step on the recipients of state actions in the search for the fulfillment of constitutional promises - which goes against the model of social administrative Law imposed in the Brazilian Constitution of 1988.

\section{References}

ALEXY, Robert. Teoria dos direitos fundamentais. 2. ed. São Paulo: Malheiros, 2014.

BARBOSA, Alexandre Fernandes et al. O governo eletrônico no Brasil: perspectiva histórica a partir de um modelo estruturado de análise.

Revista de Administração Pública, Rio de Janeiro, v. 43, p. 23-48, bimestral, 2009. Disponível em: http://www.scielo.br/pdf/rap/v43n1/ a03v43n1.pdf Acesso em: 6 nov. 2019. 
BITENCOURT, Caroline Müller. Controle jurisdicional de política públicas. Porto Alegre: Núria Fabris, 2013.

BITENCOURT NETO, Eurico. O direito ao mínimo para uma existência digna. Porto Alegre: Livraria do Advogado, 2010.

BITENCOURT NETO, Eurico. Estado social e administração pública de garantia. Revista de Direito Econômico e Socioambiental, Curitiba, v. 8, n. 1, p. 289, 23 ago. 2017.

BRAGA, Lamartine Vieira; GOMES, Ricardo Corrêa Gomes. Governo Eletrônico e seu relacionamento com o desenvolvimento econômico e humano: um estudo comparativo internacional. Revista do Serviço Público, [S.l.], v. 66, n. 4, p. 523-556, 24 dez. 2015.

BRANDÃO, Rodrigo. São os direitos sociais cláusulas pétreas? Em que medida? In: SOUZA NETO, Cláudio Pereira de; SARMENTO, Daniel (coord.). Direitos sociais: fundamentos, judicialização e direitos sociais em espécie. Rio de Janeiro: Lumen Juris, 2008. p. 451-483.

BRASIL. Tribunal de Contas da União. Guia de boas práticas em contratação de soluções de tecnologia da informação: riscos e controles para o planejamento da contratação. Brasília: Tribunal de Contas da União, 2012.

BREPOHL, Marion; GONÇALVES, Marcos; GABARDO, Emerson.

Revista Brasileira de Estudos Políticos, Belo Horizonte. n. 117, p. 321361, jul.-dez. 2018.

CORALES, Marcelo; FENWICK, Mark; FORGÓ, Nikolaus N. New Technology, Big Data and the Law. Singapore: Springer, 2017.

CORREIA, José Manuel Sérvulo. Os grandes traços do direito administrativo no século XXI. A\&C - Revista de Direito

Administrativo \& Constitucional, Belo Horizonte, ano 16, n. 63, p. 4566, jan.-mar. 2016.

CORVALÁN, Juan Gustavo. Administración Pública digital e inteligente: transformaciones en la era de la inteligencia artificial. Revista de Direito Econômico e Socioambiental, Curitiba, v. 8, n. 2, p. 26-66, maio-ago. 2017. 
CRISTÓVAM, José Sergio da Silva. 2019. Sobre a noção de bem comum no pensamento político ocidental: entre becos e encruzilhadas da dimensão ancestral do moderno conceito de interesse público. Revista de Investigações Constitucionais, Curitiba, v. 6, n. 1, p. 107-134, jan.-abr. CRISTÓVAM, José Sérgio da Silva; SAIKALI, Lucas Bossoni; SOUSA, Thanderson Pereira de. Governo Digital na Implementação de Serviços Públicos para a Concretização de Direitos Sociais no Brasil. Revista Seqüência: Estudos Jurídicos e Políticos, Florianópolis, n. 84, p. 209242, abr. 2020.

DUQUE, Marcelo Schenk. Curso de Direitos Fundamentais: teoria e prática. São Paulo: RT, 2014.

FREITAS, Juarez; TEIXEIRA, Anderson Vichinkeski. 2019. Democracia digital e avaliação continuada de políticas públicas. Revista Brasileira de Estudos Políticos, [S.l.], v. 1, n. 119, p. 227-252, nov. 2019.

FREITAS, Juarez. Direito Administrativo e inteligência artificial. Interesse Público, Belo Horizonte, ano 21, n. 114, p. 15-29, mar.-abr. 2019.

FREY, Carl Benedikt. The technology Trap: capital, labor, and power in the age of automation. Princeton: Princeton University Press, 2019. p. 309.

GABARDO, Emerson; HACHEM, Daniel Wunder. El principio constitucional de eficiencia administrativa: contenido normativo y consecuencias jurídicas de su violación. Cuestiones Constitucionales Revista Mexicana de Derecho Constitucional, Ciudad de Mexico, v. 39, p. 131-167, 2018.

GALINDO AYUDA, Fernando. Democracia, Internet y Gobernanza: una Concreción. Revista Seqüência: Estudos Jurídicos e Políticos, Florianópolis, p. 33-56, dez. 2012.

GOMES, Eduardo Biacchi; FLORES, Pedro Henrique Brunken. Formulação de decisões administrativas em matéria de direitos humanos. Revista do Direito, [S.l.], v. 1, n. 57, p. 3-21, 8 jan. 2019. 
HACHEM, Daniel Wunder. A maximização dos direitos fundamentais econômicos e sociais pela via administrativa e a promoção do desenvolvimento. Revista de Direitos Fundamentais e Democracia, [S.l.], v. 13, n. 13, jan.-jun. 2013a.

HACHEM, Daniel Wunder. A dupla titularidade (individual e transindividual) dos direitos fundamentais econômicos, sociais, culturais e ambientais. Revista de Direitos Fundamentais e Democracia, Curitiba, v. 14, n. 14, p. 618-688, jul.-dez. 2013 b.

HOFFMAN-RIEM, Wolfgang. Direito, tecnologia e inovação. In: MENDES, Gilmar Ferreira; SARLET, Ingo Wolfgang; COELHO, Alexandre Zavaglia P. Direito, Inovação e Tecnologia. São Paulo: Saraiva 2015.

IBGE - INSTITUTO BRASILEIRO DE GEOGRAFIA E ESTATÍSTICA. Pesquisa Nacional por Amostra de Domicílios Contínua: acesso à Internet e à televisão e posse de telefone móvel celular para uso pessoal 2017. Rio de Janeiro: Instituto Brasileiro de Geografia e Estatística, 2017.

IBGE - INSTITUTO BRASILEIRO DE GEOGRAFIA E ESTATÍSTICA. Pesquisa Nacional por Amostra de Domicílios

Contínua: acesso à Internet e à televisão e posse de telefone móvel celular para uso pessoal 2018. Rio de Janeiro: Instituto Brasileiro de Geografia e Estatística, 2020.

KANE, Gerald C. et al. The Technology Fallacy: how people are the real key to digital transformation. Cambridge: The MIT Press, 2019.

MACHADO, Carlos Augusto Alcântara; RESENDE, Augusto César Leite de. Tecnologia, meio ambiente e democracia: reflexões necessárias. Revista de Investigações Constitucionais, [S.l.], v. 6, n. 3, p. 749, 31 dez. 2019.

MODESTO, Paulo. Nova organização administrativa brasileira. Belo Horizonte: Fórum, 2010. 
NAÇÕES UNIDAS (Comp.). Estudo sobre governo eletrônico da Organização das Nações Unidas 2018. Nova Iorque: Organização das Nações Unidas, 2018.

NOHARA, Irene Patrícia; COLOMBO, Bruna Armonas. Tecnologias cívicas na interface entre direito e inteligência artificial: operação serenata de amor para gostosuras ou travessuras? A\&C - Revista de Direito Administrativo \& Constitucional, Belo horizonte, v. 19, n. 76, p. 83, 17 set. 2019.

NOVAIS, Jorge Reis. As restrições aos direitos fundamentais não expressamente autorizadas pela Constituição. Coimbra: Coimbra, 2003.

NOVAIS, Jorge Reis. Direitos sociais: teoria jurídica dos direitos sociais enquanto direitos fundamentais. Coimbra: Coimbra, 2010.

OLIVEIRA, Gustavo Justino de. Direito Administrativo Democrático. Belo Horizonte: Fórum, 2010.

REYNA, Justo José. Globalización, pluralidad sistémica y

Derecho Administrativo: apuntes para un derecho administrativo multidimensional. A\&C - Revista de Direito Administrativo \& Constitucional, Belo Horizonte, Ano 11, n. 44, p. 13-40, abr.-jun. 2011. REYNA, Justo José. La reforma de la Administración Pública local para la tutela de los derechos fundamentales en el siglo XXI. A\&C - Revista de Direito Administrativo \& Constitucional, Belo Horizonte, Ano 14, n. 56, p. 35-89, abr.-jun. 2014a.

REYNA, Justo José. Fundamentos del principio constitucional de actuación conjunta para la tutela especial de derechos fundamentales. A\&C - Revista de Direito Administrativo \& Constitucional, Belo Horizonte, ano 14, n. 55, p. 23-50, jan.-mar. 2014b.

ROVER, Aires José. O princípio da conexão e as perturbações estruturais no processo judicial eletrônico. Revista Sequência: Estudos Jurídicos e Políticos, Florianópolis, v. 39, n. 80, p. 202-224, jan. 2019. 
ROVER, Aires José; GALINDO, Fernando. O governo eletrônico e suas múltiplas facetas. Zaragoza: Prensas Universitárias de Zaragoza, 2010.

SANTOS, Laymert Garcia dos. Politizar as novas tecnologias: o impacto sociotécnico da informação digital e genética. São Paulo: 34, 2003.

SARLET, Ingo Wolfgang. A eficácia dos direitos fundamentais: uma teoria geral dos direitos fundamentais na perspectiva constitucional. 12 . ed. Porto Alegre: Livraria do Advogado, 2015.

SIXTEEN FILMS et al. I, Daniel Blake. United Kingdom: British Board of Film Classification, 2016.

VALLE, Vanice Regina Lírio do. Políticas públicas, direitos fundamentais e controle judicial. Belo Horizonte: Fórum, 2009.

VIANA, Ana Cristina Aguilar; KREUZ, Letícia Regina Camargo. Admirável mundo novo: a administração pública do século XXI e as tecnologias disruptivas. Interesse Público, Belo Horizonte, v.20, n.110, jul.-ago. 2018.

Justo Reyna is a Full Professor of Administrative Law at the National University of the Littoral - Santa Fé (Argentina). Former President of the Argentine Association of Administrative Law.

E-mail: justojreyna@gmail.com

Endereço profissional: Cándido Pujato, 2751. (3000) Santa-Fé, Argentina. https://orcid.org/0000-0002-4057-7731

Emerson Gabardo is a Full Professor of Administrative Law at the Pontifical Catholic University of Paraná (Brazil); Associate Professor of Administrative Law at the Federal University of Paraná (Brazil); Visiting Scholar at Fordham University School of Law (2013) and Visiting Scholar at the University of California - Irvine (2020).

E-mail: emerson.gabardo.br@gmail.com

Endereço profissional: Rua Pasteur, n. 443, apto. 1102, Batel, Curitiba, PR. https://orcid.org/0000-0002-1798-526X 
Fábio de Sousa Santos is a PhD Candidate at the Pontifical Catholic University of Paraná (Brazil); Rondônia's State Attorney.

E-mail: fabiodesousasantos@hotmail.com

Endereço profissional: Rua Imaculada Conceição, n. 1.155, Prado Velho, Curitiba, PR.

https://orcid.org/0000-0002-1079-3214 